attain to it. The physician knows there is no more arrant delusion than to suppose sickness to be a convenient season for inspiration; it is rather a season of apathy, or of despondency-Domine quid multiplicasti! At best the mystic quietism of the bedridden is not a virile enthusiasm; it is pallid and tenuous in fibre. Still it is true no doubt that the solitary and disconsolate heart, closed to common circumstance, may be more susceptible to other appeals, may offer less resistance; so that, as we have seen, anknown wells of energy may be tapped and fading and vacillating forces replenished. Then it is that the influence of a clerical minister, of a gentle friend or Bible-woman-brief angels' visits lifting up human hope and love into Divine love-may be twice blessed, blessed materially and spiritually. But even then the physician can take no active part in hypnotizing the smitten sufferer with promises of corporeal repair. Indeed in the more formal spiritual ministrations his part can never be direct; they are not obviously bis business, and even a religious patient resents the divided mind. Notwithstanding, the sick man does feel dimly that diagnosis limited to material phenomena is imperfect; that its insight ought to penetrate to mental and spiritual as well as to bodily conditions; and he would say, did he know how, Do you understand me, or am I only a case? This seems to be our modest part in faith healing; and with it these reflections must end. How tentative and inconclusive they are no one is more painfully aware than the writer himself.

\section{"SUGGESTION" IN THE TREATMENT OF DISEASE.}

$\mathrm{BY}$

SIR HENRY MORRIS, BART., M.B., F.R.C.S. EX-PRESIDENT OF THE ROYAL COLLEGE OF SURGEONS; CONSULTING SURGEON, MIDDLESEX HOSPITAL.

ALthoбgh the theory of faith healing differs from the theory of Christian Science, and that again from the theories of mesmerism, hypnotism, and animal magnetism, there is one thing which is common to them all, namely, the power of "suggestion." And by suggestion is here meant the enforcing influence of an idea.

Faith healing and Christian Science may be grouped under the term, "religious suggestion." Mesmerism, animal magnetism, etc., are now commonly spoken of as "hypnotic suggestion." All are included under " mental healing." In each of the methods of mental healing the curative effect seems to be brought about by the influence of some strong or vivid idea, of some subtle energy other than physical, upon the abnormal or morbid states of the body. To attempt to answer the question, "What is the psychological process by which this power or energy'suggestion'-works the cure?" would require a consideration of the theories of "unconscious mind" of " unconscious cerebration," and of "dual mind," or in other words, the relation of the conscious or objective side of the mind to the subjective or subconscious side. It must suffice to say here that the most accredited theory at the present tim as to the states of mind induced by hypnotic or religious suggestion is that the objective side is thrown into abejance, whilst the subjective is brought into a condition which enables it to receive suggestions.

The readiness with which the subjective mind can be reached varies greatly in different races of men and in different persons of the same race. The French, for instance, are found to be more susceptible than the English. Some persons pass spontaneously into the hypnotic state, others are not at all amenable to either hypnotic or religious suggestion. Some are affected against their will; others, though willing and even anxious to be hypnotized, remain unaffected.

Esdaile, it is said, on one occasion hypnotized a man in open court behind his back and without his knowledge. Some operators are more successfal than others. Some cannot hypnotize at all. Thus, it would seem that in some individuals the objective mind cannot be put into abejance either at the wish of the person himself or at the will of another. Again, different subjects, even though susceptible to an equal degree, show very different phenomena under the influence of hypnotism. In some, ordinary consciousness is lost, and sleep, trance, catalepsy, or somnambulism results, the subject rendering absolute obedience to the operator and on waking being unaware of what has passed. In others the effect of suggestion is marked by an exalted intellectual or emotional power, or by the acuteness of one or other of the special senses being so beightened that the subject is able to do things which he is quite incepable of doing in his ordinary state.

\section{MENTAL SUGGESTION.}

Hypnotic and religious suggestion are quite different from what is understood in metaphysics as mental sug. gestion. In psychology and metaphysics the term " mental suggestion" is used as the equivalent of "mental association" or the "association of ideas." It is employed to account generally for the facts of mental life, and to express in a general way the principle which Berkeley applied specially to the problem of visual perception-namely, that one idea may suggest another idea to the mind if these two ideas have been associated together frequently; and that, too, without our having any proof of the necessity of their co.existence, and without even knowing what it is that makes them co-exist.

The principle of "association of ideas" was pointed out by Aristotle, but the expression was first employed by Locke. Subsequent philosophers, especially Hamilton and Hartley, urged that association extends beyond ideas or thoughts proper to every class of mental states.

Hartley being a physician by profession as well as a metaphysician, in his Observations on Man, published in 1749, combined the doctrine of mental association with a detailed hypothesis as to the corresponding action of the nervous system, and he enunciated the principle that any sensation frequently associated with another sensation will, when presented alone, call up in the mind the ideas which are excited by that other sensation also. James Mill carried the doctrine still further than Hamilton, Hartley, and Berkeley, and beld that "some ideas are by frequency and strength of association so closely combined that they cannot be separated; if one exists the other exists along with it, in spite of whatever effort we make to disjoin them." And John Stuart Mill made the same statement, though in somewhat more guarded terms, as to the "inseparable" character of the association of certain mental states.

Thus it is apparent that "suggestion" as a force in producing mental cures concerns the influence exercised by another person, or by some other external agency, upon the mental and physical states of an individual; whereas "mental suggestion" is the spontaneous recurrence of trains of thought in the same individual. "Mental sug. gestion" is a psychological process absolutely distinct from hypnotic and religious suggestion. Indeed John Stuart Mill sought to prove that "inseparable association" is the ground of our belief in an external objective world; whereas Christian Science denies in toto the existence of such a world, and under the term "Mortal Mind," which Mrs. Eddy uses as " the specific term for error," she refers to the body and to the whole material world as non. existent.

\section{HYPNOTIC SUGGESTION.}

Suggestion as a powerful agency was not unknown to Mesmer, but its significance was overlooked by the earlier Mesmerists, who adopted instead the theory of the "magnetic fluid" in explaining their influence over patients

James Braid, of Manchester, who, in 1841, originated the word "hypnotism" denied that the mesmeric phenomena were caused by the "magnetic fluid," though he himself made use of mesmeric "passes." Braid, the hypnotist, the propounder of the theory of "nerve sleep," appreciated the importance of suggestion better than Mesmer; and Braid's followers, who anticipated the celebrated Nancy school of hypnotists, developed the theory of suggestion to a considerable degree. According to Braid, "the sleeper" shows "physical manifestations of the suggestion received through words, or excited by sensible impressions which thereby direct his current of thought"; and he farther taught that "definite physical changes could be excited and regulated and controlled at will, according to the suggestion of another person."

In 1851, both Dr. Gregory of Edinburgh and Dr. Hughes Bennett described the phenomena of hypnotism as due to suggestion; and Bennett's view was that the predominating ideas which excite the phenomena of 
mesmerism may be either of spontaneous origin or sug. ge: tel by the wurds and actions of others.

Dc. Liébault, the founder of the Nancy school (1880) of bypnotists, declared that there is nothing in bypnotism except suggestion. Indeed, most mental scientists of the present day are agreed that the basis of mesmerism and its effects is a marked susceptibility to suggestion, the mind, including the will of the subject, being ready to receive and act upon any idea impressed upon them by the operator.

It is evident from what is now known that animal magnetism, electro-biology, clairvoyance, odic force, mesmerism, and hypnotism are essentially one and the same thing, which has undergone a series of revivals under different names. They all have had the same origin, and the same history; and while the different names predicate different theories, they do not in reality stand for any difference in method.

It would appear that in all ages hypnotism has been known, though not under that name, as a means of curing diseases. It is also known that amongst the Greeks and Romans, and in many Oriental nations in olden times, priests performed cures by throwing people into deep sleep; and that in England in the seventeenth century several individuals claimed to have power of healing the sick by stroking with their hande. Such influences were pretty generally held to be supernatural and connected with religion. Since the eighteenth century the hypnotic state has been induced in a number of ways precisely like those used in producing the mesmeric "crisis." In the latter quarter of the eighteenth century Mesmer and his immediate successors in Paris employed mesmerism as a curative treatment for disease. This practice was stopped by the French Revolution, but about the year 1820 it was again widely adopted in hospitals, and minor operations were performed under its influence. In 1831 a commission of the Académie de Médecine, after an inquiry extending over five years, issued a report in favour of the reality of the mesmeric phenomena. A later inquiry instituted by the same body was, however, followed by an unfavourablereport.

In 1843 Esdaile, a Scottish surgeon, successfully made use of mesmerism on a large scale in India as an anaesthetic agent for major operations, though he did not regard it as a remedy for all kinds of diseases. In 1851 Dr. Gregory declared that, in his opinion, hypnotic suggestion had a useful and increasing application in medicine; and in the same year Dr. Hughes Bennett, referring to Esdaile's successfal work in India, expressed the view that before long mesmerism would become acknowledged as a rational means of treating diseases. Charcot in 1877-80, when investigating the treatment of hysteria by metal plates, stumbled upon the hypnotic or mesmeric state just as Mesmer himself had done in 1774, and, owing to Charcot's great name and fame, hypnotism took a fresh start in France, and once again became recognized as an orthodox method of treatment. In 1889 an International Hypnotic Congress was held in Paris, and was attended by leading representative men from all Europe and from North and South America. The result of this conference was to give hypnotism a great stimulus and to raise sanguine expectations as to the usefulness of it in medicine. Bat in spite of the complete vindication and recognition of the reality and existenc $\ni$ of the phenomena of mesmerism, and in spite of the thorough trial of it in the treatment of disease at certain epochs between 1820 and 1889, to which I have just alluded, it has never long maintained a hold upon the medical profession. Its successful employ. ment has for the most part been limited to disorders of the nervous system, the relief of pain, the cure of dipsomania, and the production of anaesthesia. The Nancy doctors, after Charcot in 1880 revived attention to the hypnotic or mesmeric condition, employed it in every class of diseases, including the specific fevers, but with incon. spicuous success. Charcot came to regard the hypnotic state as a morbid condition allied to hysteria, and abandoned it because, as he said, it did more harm than good, and added to the disorder of already disordered nervous systems. Nor was its utility extended or confirmed by longer experience in the practice of others.

Though hypnotism has from time to time been revired, and there have been periods when it excited great interest on account of its positive effects, it has invariably fallen back again into disfavour, owing to the uncertainty of its action and its failure on a large scale as a therapentical agent. Moreover, it has been found too dangerous for general use in medical practice; and in order to produce a state of anaesthesia sufficiently profound for the perform. ance of surgical operations the patient must be made highly susceptible by repeated hypnotization, extending over weeks, and in the course of the process he is pretty sure to have his will power permanently enfeebled (Shadwell).

For these reasons the profession as a whole has been fully justified in holding aloof from the practice of hypnotism; and a knowledge of what has been done in the past ought to be an effective discouragement to every proposal to return to it either now or in the future.

\section{RELIGIOUS SUGGESTION.}

Religious Suggestion includes (A) Faith Healing, and (B) Christian Scienco.

\section{a. Faith Healing.}

In faith healing the suggestion is that cure will be worked by spiritual or divine power, especially if this power be appealed to at some particular place such as a sanctuary, the foot of an idol, a fountain or pool of water, the resting place of some sacred relics such as the bones of a saint, or, it may be, in presence of the Eucharistic procession or during High Mass or the administration of the Holy Sacrament. Healing power is also believed to reside in the touch of a king, and in that of a seventh son of a seventh son, and also in the incantations of a "wise woman."

This divine power, or energy, is supposed to act by neutralizing or overcoming sickness, disease, and the ill consequences of accidents. The faith healer does not doubt the reality of matter or of diseases, but believes that he can draw upon a spiritual force to subdue or annihilate an existing evil.

\section{Louräes Cures.}

Conspicuous amongst the cases of faith healing are the Lourdes cures.

Charcot describes these as cases of hysteria and of other neuroses, cured by religious suggestion; Bernheim speaks of them as cures by suggestion; Berillon as cures by hypnotism. On the other hand, Dr. Boissarie, the chief of the "Burean des Constatations" at Lourdes, repudiates all such explanations and declares that they are supernatural effects and nothing less than miracles. Faith healing and hypnotic suggestion, he points out, are forms of "treatment by an idea," exercisable upon only a very limited range of disease. In such healing the only curative intervention is the power possessed by the mind over the body; beyond this range faith healing clashes with that impassable barrier-the laws of Nature. But at Lourdes, he tells us, there is no limitation in the character of the cases cured.

Tumours, wounds, and all sorts of organic diseases in others than neurotic patients, diseases which bave resisted all forms and varieties of medical and surgical treatment, are cured, and cured instantaneously, at Lourdes. Some of the patients recover after drinking at the spring of the grotto, some after bathing in the pools there, some during the Eucharistic processions, others at or after attending Mass or partaking of the Holy Sacrament, and others again by praying quietly and in solitude at the shrine of the Immaculate Virgin.

Cancers disappear, tuberculous ulcers cicatrize, perforations of the cheek and palate are instantly and perfectly filled up, gastric ulcers heal, the blind are given sight, and suppurating joints, taberculous peritonitis, necrosis of bones, gangrenous feet, etc, are made well in the twinkling of an eye. Indeed, it seems only necessary for some individuals merely to touch the soil of Lourdes to be instantaneously restored to health. Suggestion, Dr. Boissarie tells us, whether religious or hypnotic, is as a curative agency at best very limited, being confined to patients affected with simple fanctional troubles, or broken down in health from overwork, whilst serious cases of hysteria may even suffer harm instead of being benefited by it. But at Lourdes there are but few functional troubles, whereas, on the other hand, persons with all sorts of different organic diseases are made well either during their sojourn in the place or after they have returned home therefrom, quite independently of any influence of suggestion.

These supernatural manifestations not only surpass the possibilities of art and science and the ordinary limits of the powers of Nature, but they actually turn the laws of Nature topsy-turvy. The inference to be drawn from 
Dr. Boissarie's descriptions is that the miracles performed through the Immaculate Virgin at Lourdes are even more wonderful than those of her Son and His Apostles. Their works, though exceeding in extent the ordinary powers of Nature, never contravened the processes of Nature, as we Aearn from the readiness with which Christ turned water into wine but refused to change stone into bread, or to cast Himself down from a pinnacle of the temple to prove that the angels who were given charge of Him would bear Him up, and prevent Him suffering any physical hurt.

It is useless to discuss the character of the cases cured at Lourdes, or to dispute the opinions entertained in favour of the view that these cures are of a miraculous and super. natural order. The polemics of the subject will never sease. And certainly it would be foolish to deny the occurrence of extraordinary events at Lourdes, and unwarrantable to question the sincerity and bona fides of Dr. Boissarie and his colleague in charge of the "Bureau des Constatations," from whose notes and records we derive much information. But I confess that, after a careful perusal of Dr. Boissarie's book L'Oeuvre de Lourdes, I am not convinced of the correctness of his views or of his interpretation of the remarkable cures he has related therein.

I am in sympathy with the attitude adopted by Pro. fessor Fournier and Dr. Besnier, of Paris, to whom the zotorious case of Madame Rouchel was referred in 1905. This was a case of lupas of the face with perforations in the cheek and palate, and extensive tuberculation and alceration of the lips and other parts of the face. The report is that both these perforations were instantaneously healed in so complete a manner that it seemed as if there had never been any loss of substance.

The woman came from Metz, and sometime after her return she was made the subject of debate at a conference of doctors there, at which Dr. Boissarie was present. Br. Maller, the skin specialist of Metz, in particular declined to accept the case as one of veritable instantaneous cure, in the absence of any medical evidence as to the condition of the disease immediately before the moment of asserted cure. And no one can censure Br. Maller for his incredulity, seeing that the only evidence in support of the condition of the woman's face just before she was healed was the testimony of a hospital nurse and a religieuse, and the casual observa. tion of a bath attendant, a publicist en route to the grotto, and a chance visitor to Lourdes in the person of a school teacher. But no medical evidence was forthcoming beyond that contained in certificates, and no medical man had seen the case later than eleven days before the asserted miracle of the instantaneous healing of the perforations in cheek and palate.

The Paris professors mentioned above declined to act as arbitrators in the dispate between Drs. Muller and Boissarie; and although they made a very prolonged and detailed examination of the woman's case, they refused to pronounce an opinion as experts in medicine on what had occurred at Lourdes. They remarked that it is not in the interest of religion to confuse scienco with religion; but that they should have supposed it would have given the Holy Virgin no more trouble to com. pletely cure the lupus than to fill up the perforations in the cheek and palate, leaving, as sbe had done, the Iupus tubercles on the nose and cheeks and the ulcers on the lips uncured and without improvement.

I gather from Dr. Boissarie's writings as well as from J. K. Huysmans's book, Les foules de Lourdes, that it is not the custom for the doctors in attendance at the Bureau des Constatations to examine the pilgrims on arrival at Lourdes, nor, in fact, until the healing is in course of being accomplished, or after it has been actually effected; so that the registers do not contain reports made by the medical attendants from their own personal observation of the patients between the arrival of the patients at Lourdes and their first visit to the grotto. The reports by the patients of their own ailments and of the failure of all previous treatment, read in many instances Aike sombre fairy tales-they are related with so much emotion and often with ecstatic enthusiasm.

Comparison of Lourdes Cures with Cases met with in Ordinary Practice.

There are none of the magnificent manifestations of Lourdes which I have read of which could not be paralleled by cases in the practice of medical men of wide experience. The case of Mdlle. Lévêgne, claimed by Dr. Boissarie to be one of the most strikingly important ever seen at Lourdes, is easily explained by the escape during the woman's journey or just after her arrival of a fragment of necrosed bone from the inflamed, suppurating, and painful wound.

A case of immediate closure of " a sinus left after appendicitis" is a not uncommon surgical experience in connexion with the escape of a deep suture or ligature which has been keeping open a sinus following an operation, whether of appendectomy or for radical cure of hernia, or for one of many other conditions. The escape of the peccant loop of silk is very likely indeed to be overlooked unless close watch is kept for it, and both nurse and patient are surprised when on removal of the dressing the sinus is found healed.

The case of Mdlle. Rosarie Monnier, a young lady brought to death's door by starvation, is specially accentuated in Huysmans's description of Lourdes as being "une maladie de langueur" not due to any well.defined cause, because the sufferer had been abandoned by science and declared to be beyond the possibility of even the slightest relief. At length, after nineteen years of illness, she had a "sudden intuition that she would obtain her cure from the Immaculate Virgin if she went willingly to Lourdes." She went, and was instantaneously cured on the morning following her arrival, and just after receiving the Holy Communion at the chapel of the hospital of the "Holy Lady of the Seven Sorrows"-the hospital in which she had passed tho night.

I am aware of a case which must be perfectly well remembered by a distinguished London physician still in practice, as well as by a member of the profession at Bournemouth, which, except for the youth of the patient and the much shorter duration of the symptoms, was remarkably like that of Mdlle. Monnier. This little girl, the spoilt child of loving and despairing parents, was cured within twelve hours after entering a nursing home in London, to which she was most unwillingly transferred. and where she was most reluctantly allowed to go by her parents.

In my own experience there have been several cases of hysterical or purposive deception, simulating real diseases, which were instantaneously cured, and which in their way are quite as remarkable as those we hear of from Lourdes and other shrines and sanctuaries.

A woman supposed to be hopelessly ill with a communi. cation between her stomach and a dilated renal pelvis was immediately made well by our detecting her spitting finely masticated food into ber urine. Another woman who was admitted into the Middlesex Hospital under my charge was supposed to be afflicted with cancer of the uterus and vagina. Her symptoms were discharge and pain, and actual perforation of recto-vaginal and resico. vaginal septa. She had been ill for years; but she made a most rapid recovery after I removed a candle extinguisher from the upper part of her vagina. An unmarried woman living by herself with her cervants bad been for a long time the subject of a peculiar skin rash which had frustrated all treatment, and was a puzzling and unique case in the experience of the late Sir Erasmus Wilson. She recovered at once after being seen early one morning on a surprise visit from her medical attendant fric. tionizing her skin with a piece of pumice stone. Another young lady was sent to me with a chronic sore on her thumb. It had resisted scraping and every sort of medical treatment. One day she was caught hiding away a box containing the sticks of wooden matches sharpened to a fine point. She was charged-and confessed after indignant protestations at being suspected and accusedthat she was keeping open this wound by irritating it with the pointed match stems. Her object had been to get away from home for treatment, as she was very unhappy with a newly made stepmother. She was terribly afraid of her fraud becoming known to her relations, and. I promised to keep her secret unrevealed to others on condition she came to me in a week with the wound quite sound, and promised never again to make it sore. To the best of my knowledge, we have both been faithful to our vows up to the present time.

A charming and very handsome girl who craved to go on the operatic stage, but was opposed by ber family in doing so, was very anxious to take lessons at the Conservatoire of Music. Consent not being given to this 
scheme, she became afflicted with a troublesome and persistent sore throat. This excited sympathy, and she was, after a time, permitted to quit her "damp and relaxing" neighbourhood for a residence in Paris. At once, after this " change of air," she gave up applying carbolic acid to her tonsils and fauces, and her sore throat got rapidly and permanently well.

To these cases of feigned or self-induced disease I will add the mention of two cases of immediate recovery from real disease.

A woman absolutely at death's door, pallid and helpless from many repetitions of loss of blood, was admitted into my cancer ward at the Middlesex Hospital. I found the cause of her condition was not cancer, but a large uterine polypus with a slender pedicle and a surface black, roughened, and sloughy from the application of strong ferric astringents. For a day or two I feared even to have her moved on to the operation table. When I did so, and placed her in the lithotomy position, the polypus fell unassisted bodily to the foor, and from that moment she began to get well.

A man who for a long while had been suffering from chronic intestinal obstruction and haemorrhages was admitted into the Middlesex Hospital under me. He had previously been in two large London hospitals, and had been told by surgeons, one a very distinguished man only recently deceased, that he had malignant disease of the rectum, and must be operated upon. He had refused at each of these hospitals to undergo an operation. Colotomy had been the operation proposed to him at one of them. I found he was suffering from a large polypus of the rectum, and its removal at once completely cured him Many times afterwards he visited the hospital to report himself to me, and was seen by my dressers and housesurgeons in excellent health.

I could add other cases if it were necessary, but those I have mentioned are sufficient, both in number and in character, I think, to justify my scepticism as to the miracles of Lourdes, and as to the remarkable cures there being due to the immediate and direct interposition of the Divinity.

Nor am I tempted to give up my unbelief because "the extraordinary facts of Lourdes" which were communicated to the Holy Father at Rome by Dr. Boissarie on the eve of the Jubilee of the Apparition of the Immaculate Virgin to the shepherdess Bernadette at Lourdes were investigated to the satisfaction of the "Curia" or Court of Inquiry of the Papal See, and thereafter received the seal and confirmation of "The Church."

Nor can I altogether, or even almost, persuade myself to forego forming an independent opinion about these cures, because I am assured on the authority of the Bishop of Tarbes that science has its limits, and that it is the mission of the Church alone to pronounce on the reality of miracles, after canonical inquiry has ascertained evidence of "the finger of God and the direct intervention of His power.'

These episcopal ordinances which declare the miraculous nature of the Lourdes manifestations naturally arouse a desire to know somewhat of the history of the "Lourdes movement." By this way we shall be able to get a better idea of the real significance, the inwardness, of these performances at Lourdes.

History of Lourdes and Former Shrines.

"The apparitions of the Holy Virgin in our own epoch, such as that in the grotto of Massabieille at Lourdes, are not in any way surprising; Lourdes, in the history of France, is neither an exception nor a novelty. The Mother of Christ has looked upon that country as her own property ('fief'). At no time, save in the 18th century. has she disinherited it of her continuous presence; but if one thinks of the frightful baseness of the Bourbons and the inexorable infamy of the Jacobins this temporary abandonment is explained." So writes M. Huysmnns in the eighth edition of his work above referred to.

Lourdes, in fact, is but a modern and the latest repetition of many similar manifestations which have been seen in Paris and in the provinces of France. Lourdes is the centre of a district in which were nine chapels, formerly the resorts of pilgrimages to the Madonna; and it stands surrounded by these ruined and now unfrequented sanctuaries "like a brilliant star surrounded by nine waning satellites." These chapels were built at different periods between the latter part of the fourteenth and the early part of the seventeenth centuries. The dates at which they ceased to attract pilgrims and became more or less ruins are lost in the obscurity of time. Some of the chapels were destroyed by the Huguenots, some were deserted on account of their inaccessible situations, some because of the cupidity and licentiousness of the neighbouring inhabitants, which "caused the Virgin to with draw" from these places. And for this latter reason-the extortion and dissoluteness of some of the residents-it is predicted that she will in time retire from Lourdes also.

But this much about these chapels is sure: scarcely one of them in their day lacked any of the accessories of their successor on the banks of the Gave. Grotto, spring. shepherdess, and miraculous cures-all were theirs; but, above all else, there was at each of them the radiant presence and effulgence of the Virgin Mary.

Lourdes, therefore, is the resultant of the revivification. by the Madonna of ancient devotions formerly so popular in other and neighbouring spots in the Pyrenees and in the French capital. In Paris in the fourteenth century an altar and a brotherhood under the name of the Immaculate Conception were instituted in connexion with the Church of St. Severin, to celebrate the spotless purity of the Virgin Mary. "This devotion was rewarded by the Virgin curing multitudes of sick persons who came, often from far away, to drink of the water of the wells at the foot of the statue. . . . But by degrees this devotion grew feebler and feebler, and Saint Severin ended by being a parish church instead of a sanctuary for pilgrims."

In the seventeenth and eighteenth centuries it was made a rendezvous of the Jansenists, and though dead as a shrine of the Virgin, it became a branch estab. lishment of the cemetery of St. Medard, where the "Convulsionists" resorted to pray at the tomb of the Abbot Desanguis, the Deacon Confessor of Paris.

To-day the Virgin, if she still dispenses spiritual benefactions at St. Severin, has, it would seem, at any rate closed her "dispensary" for bodily ailments, and the wells have been closed up by the priests since the waters have been forsaken by the pilgrims.

In the fourteenth century the devotion to the Immaculate Conception was very marked in Paris, but onwards from the end of the Middle Ages it dwindled day by day; there was no longer any special shrine for the purpose, but her worship shifted about (vivotait) from place to place till in November, 1830, the Virgin suddenly desired to make a fresh start and spread abroad her influence, not only in Paris, but throughout the whole world. Then it was she appeared to Catherine Laboure in the chapel of the Sisters. of Charity, in the rue du Bac, and commanded this sister of St. Vincent de Paul to have a medal struck wherewith to propagate the belief in the Virgin's immaculate origin.

About the same moment a voice spoke to the cure of the church of Notre Dame des Victoires, when he was celebrating Mass, and told him to consecrate his parish " to the very sacred heart of the Immaculate Mary." The effects were prodigious; the medal rapidly became celebrated for its miracles, crowds were drawn to the chapel in the rue du Bac, whilst on the other side of the Seine the hitherto empty church of Notre Dame des Victoires, situated in one of the most debased districts of the town, became filled to overflowing, and physical cures and spiritual conversions were achieved there in great numbers

The special hyperdulia of Lourdes is a replica on a larger scale, and in a place accessible to the whole country, of the worship at Notre Dame des Victoires in Paris. Sixteen years after the apparition of the rue du Bac and the hearing of the voice by the curé of Notre Dame des Victoires, and twelve years before the apparition at Lourdes, the Virgin appeared to a little shepherdess at La Salette in the Alps. This was in 1846. There also a spring of water gushed forth and miraculous cures were wrought. La Salette, like Lourdes, was surrounded with ancient pilgrim chapels more or less ruined and extinct.

For a time La Salette had a wonderful name, but the bad roads, the difficult ascent to it, and the miscreant and scoffing Freemssons of the district led to its desertion, and the final blow was struck at it by the apparition at Lourdes at the base of the mountains instead of on the summit of a peak difficult to climb.

The Virgin appeared at Lourdes with a countenance smiling and radiant and as if she desired to be more easily approached-more within the easy reach of the people: and there she distributed benefactions with both hands. 
This was quite different from the austerity and sadness of her apparition at La Salette, where she was seen weeping and threatening, and was heard censuring the vices of mankind, more especially those of the priests and the cloisters. At La Salette not a word was said by her about the spotless purity of her conception, and her blessings and benefits were dispersed in a far less liberal manner than afterwards they were at Lourdes.

At Lourdes, in 1858, the Virgin's words to Bernadette were distinct and emphatic: "I am the Immaculate virgin. I desire a chapel here."

\section{The Relation of Miracle Cures to the Doctrine of} the Immaculate Conception.

Let us now consider briefly the bearing which the con. troversy about the Immaculate Conception had upon these shrines and chapels to the Virgin in Paris, the Pyrenees, and the Alps.

This dispute commenced in the twelfth century by the canons of the Cathedral at Lyons introducing into their church a festival in celebration of the Immaculate Virgin without consulting the Roman See. These canons are said to have learnt their special rite from a document communicated by the Virgin herself.

At once, a remonstrance and a critical argument ridiculing the doctrine was sent to the canons by Bernard of Clairvaux (St. Bernard). During the thirteenth century the Feast of the Conception became very popular, and in 1263 it was accepted by a general chapter of the Franciscans at Pisa, but without reference to the question of im. maculacy; during the same century, however, all the leading theologians took the view of St. Bernard. Then in the early part of the fourteenth century came the categorical statement of the doctrine of the Immaculate Conception by Duns Scotus, the "subtle doctor of the Franciscans," and its denial by Thomas Aquinas, the learned Dominican-" the Dominican Aquinas" as he was called. But the doctrine was gaining ground, and in 1387 the University of Paris condemned one of its members because he taught that the Virgin Mary, like other descendants of Adam, was born in original sin; and the university expelled the Dominicans, who were fierce opponents of the doctrine of the ImmacuIate Conception. For several years the Dominicans were excluded from all the privileges of the university because of their continued refusal to acquiesce in its teaching.

It was at this same period, as we have just shown, that the pilgrim chapels in the Pyrenees and Alps took origin, and that the worship at St. Severin in Paris became especially associated with the Virgin.

In the beginning of the fifteenth century the University of Paris made subscription to the doctrine a necessary condition for its degrees; and various other universities entered into a compact to do all in their power to propagate it. But, on the other hand, at the end of the same century-namely, in 1483-Pope Sixtus IV published a Bull threatening with excommunication any one making charges of heresy against either the advocates or the impugners of the doctrine, for the reason that the point had not yet been decided by the Apostolic See.

In the middle of the sixteenth century (1546), the Council of Trent sought to effect a compromise between the Dominicans and Franciscans.

In the seventeenth century under the influence of the Franciscans and Jesuits in Spain, pictares were painted, statues erected, and persecutions set on foot in honour of the "Virgin conceived without sin"; and embassies were sent to Rome by Philip III and IV, to obtain more explicit recognition of the then popular doctrine. The Popes, however, continued to maintain an attitude of reserve. Pope Paul V in 1617 forbade all public disputation on the subject, and Gregory XV in 1622 went still further, and even prohibited private discussions, except in the case of Dominicans amongst themselves. This discouragement, or at least this lack of encouragement, of the doctrine of the Immaculate Conception had its effect on the pilgrimages; and consequently there commenced a little later the desertion and destruction of the pilgrim shrines to the Virgin, and the cessation of the miraculous cures at these special places in the Pyrenees and Alps. It was this lukewarmness towards or this indifference to the doctrine of the Immaculate Conception which in all probabiliby led to these sanctuaries becoming neglected; and not " the appalling baseness of the Bourbons and the inexorable infamy of the
Jacobins," which Huysmans assigns as the cause why the Virgin disinherited France during the eighteenth century of her beneficent presence.

But by degrees the papal view became more defined, and more in favour of the doctrine, and at length Gregory XVI (1831-1846) gave permission to several prelates to describe the Conception as Immaculate. And now it was that the Holy Virgin, who had never before mentioned the subject of her freedom from original sin, spoke in 1830, for the first time, of her prerogative in this respect when she revealed herself to Catherine Labouré in the rue du Bac, Paris.

Between his accession to the Holy See in 1846 and the year 1854 Pius IX made communications with the bishops inviting them to state how far the papal pronouncement in favour of the dogma would meet their wishes and the wishes of those under them. And as if to incline the priesthood to penitence and remorse, and to lead them in the direction desired, and to stimulate their attachment to the Virgin, La Salette-where the Virgin appeared with a weeping face and lamenting the vices of the priests-Was founded in 1846, and its fame and its miracles were soon spread through. out the world. The replies to the Pope's address were in the great majority of instances declarations in favour of the dogma, and the result was that on December 8th, 1854, the Pope formally declared his approval of the doctrine of the Immaculate Conception before an immense congregation of cardinals, patriarchs, archbiehops, and bishops assembled in St. Peter's at Rome. Meanwhile the nineteenth century itinerary of the Virgin, which began in Paris in 1830, and for a brief space made a halt at $\mathrm{La}$ Salette in 1846, was to find its ultimate destination at Lourdes on February 11th, 1858. It is to be noted that this date is four years after the declaration of the dogma of the Immaculate Conception by the Pope in St. Peter's had been solemnly announced, whereby the dogma was made an article of faith, and its denial declared to be heresy.

Then the Holy Virgin spoke out plainly to Bernadette in the grotto of Massabieille and said: "I am the Immaculate Conception." She had waited through all these centuries, through all the period of disputations in the Middle Ages; she had almost ceased to receive special devotions and to dispense hen special benefactions in the seventeenth and eighteenth centuries whilst discussions were forbidden and the decision of the Roman See was held in suspense; and then, at last, she came to the front again with the revival of the discussion in the first portion of the nineteenth century. On former occasions it was "Mary conceived without sin," but now, after the head of the Holy Roman See had decided the question in her favour, she appeared in all the glory of her resplendent halo and absolutely identified herself with her prerogative "Immaculate." Then was the dogma of the Conception made manifest to all by the "events of Lourdes." Then the Lourdes miracles commenced.

It is obvious to any one who will follow the course of the dispute about the Immaculate Conception step by step with the history of the shrines and apparitions in Paris and the Pyrenees that there is a remarkable chronological relation between the vicissitudes of the doctrine on the one hand, and the popularity or otherwise of the worship and the accompanying performance of miracles at these shrines, on the other hand. With the rise and fall in favour of the doctrine of the Immaculate Conception rose and fell the number of pilgrimages and of miracle cures.

After 1854, it became heresy not to accept the doctrine; the people had to be instructed as to it; the well.to.do and educated could be otherwise informed, but the lower classes and the peasant ignorance had to be enlightened; and by what means could this be more strikingly accom. plished than by appealing to the imagination and the superstition of these folks, through reports of apparitions and by the emphatic declaration of the Virgin herself, "I am the Immaculate Conception"? And if, as the reward of the people's belief, these reports were followed by benef. cent and miraculous cures of physical ailments, as well as by spiritual conversions, so much the more impressive and convincing would be the instruction of the Church. The events at Lourdes, it is said, hallow and confirm the instruction given by the Church. They tend to bring the dogmas of the Vatican into popular favour.

More recently we have heard of another instance of the 
same sequence of events. In 1905 the Holy Father recommended "frequent communion," and this decree has been followed at Lourdes by " the multiplication of more brilliant cures in connexion with the Encharistic procession, the Mass, the elevation of the Host, and the Holy Communion." Unmistakably "we find in this fact a response from heaven to the teaching of the Church."

We are told that at the present moment, in spite of the multitudes of pilgrims who pray there, only very few actual miracles are being wrought at the grotto; and that this is due to the great number of tourists who now go to Lourdes in automobiles from all the surrounding Pyrenean spas, prominent among whom are the forward and self. assertive English with "l'indigence de cervelle" (mark the word) "et de la misère d'âme de ces funestes snobs," etc. (Huysmans). The Virgin, displeased with the behaviour of the hale and hearty, withholds her benefactions from the sick and suffering! History thus proves to us that political and social events can disarrange the healing disposition of the Immaculate Virgin, as well as of the mesmerists. The automobile craze suspends the miracles of the one; the great revolution, as previously stated, put a stop to the activity of the other.

And if it be asked, "How came it about that the Alps and the Pyrenees, the dioceses of Bayonne and Tarbes, were so specially selected as the places at which these apparitions and miracles occur?" one is disposed to attribute the chief reason to the mountainous character of the country.

It is not entirely because the Holy Mary had always looked upon France as the country peculiarly her own (Huysmans); nor because on the other side of the Alps is the country which contains the apostolic capital of the world, and on the other side of the Pyrenees the country in which dogmatism, fanaticism, and superstition erected the Inquisition. Not entirely because France, Italy and Spain are the great Roman Catholic countries of the world, but chiefly, no doubt, for the reason that the inhabitants of the mountain districts are more impressionable to these manifestations. As Alison ${ }^{1}$ in his remarks on the Tyrol states, "the grandeur of the mountain scenery imbues the minds of the natives with fear, and has caused the invention of many superstitious legends." It may be doubted if in the northern parts of that land so favoured of the Virgin the apparitions of herself would have taken the same hold on the imaginations of the French common people as they did upon the more imaginative and emotional inhabitants of the Pyrenees. Much might be said on this subject, bat I must content myself by referring the reader to Buckle's History of Civilization (chap. ii, vol. i) for information as to the effect on the moral and religious character of the people of the physical conformation of the country in which they reside.

Thi Creative Lir.

One of the greatest social forces in almost every country and in almost every epoch is the creative lie. It is one of the most potent factors in the world. Alike with the educated citizen of a great city and with the ignorant peasants of a mountain hamlet, a mere statement forcibly advanced and plausibly supported at once becomes a belief. No question is asked. No doubt as to the truth of the announcement is raised. Thus, it is too often the case that to prefer a charge is to convict of an offence. "Give a dog a bad name and hang him" is an old apophthegm. A charge made, whether about a person or thing, is frequently taken as proven merely because it is rumoured. How many people have the faculty of being quite sure a lie is a trath if only it is repeated a number of times, even if the only persons repeating it are them. selves! What multitudes prosper by the fabrication of the not yet true! How often the constructive rumour becomes the procleimed belief! In Daguid's History of the Stock Exchange there is an interesting account of the "De Berenger Fraud" or "The Napoleon Hoax" of 1814.

In that year Government Funds had been heavily depressed by the success with which the French were withstanding the attacks of the Allied Armies. But on Monday morning, February 21st, 1814, the whole aspect of the Stock Exchange was suddenly changed by rumours, as vague as they were welcome, which reached the House, to the effect that the Allied Armies were in possession of Paris, that pezce was assured, that Napoleon was slain. There was no official announcement, no authoritative foundation, only a certain amount of circumstantiap evidence. This took the form of De Berenger himself, disguised as an aide.de.camp to Lord Cathcart, his gorgeous uniform wet with the spray of his crossChannel voyage, scattering with his tidings napoleonsnot sovereigns-at every stage of his journey, and shower. ing amongst the eager and excited people, as he drove with his two accomplices in triumphal procession through the City of London in a carriage drawn by four horses and bedecked with laurel, papers announcing again the fall of Paris and the death of Napoleon.

The fraud caught on completely ; omnium rose from $27 \frac{1}{2}$ to 33, and De Berenger sold out more than three-quarters of a million sterling of Government stock at a profit of about ten thousand pounds.

At length it was discovered that the rumour was false; omnium and Consols crashed back to their lowest figure, and the chagrin of the Stock Exchange at having been. thus duped was, needless to say, extreme.

This is an illustration of the power and the effect of the creative lie. Bat we need not go back a hundred years for examples. "Rabber shares are in great demand!" "People are going in crowds to Somebody's to buy short skirts !" Only placard these statements thickly through the town, send out sandwich men, advertise widely in the press, and the eagerness for rubber shares knows no bounds; the demand for short skirts at the shop named becomes enormous, though previously the public had never heard of rubber shares, and Somebody bad not \& short skirt in their establishment. It is the same in political strife, and in actual warfare. A false belief of one day becomes the truth realized another. The false, but accredited rumour, "The enemy are beginning to retreat," if spread throughout the ranks, produces such an effect that the enemy actually do give way. The constructive look, and the suggestive sound, as well as the spoken lie, will equally bring about the not yet true.

The bardit, or war song of the Ancient Germans, Tacitus tells us, inflamed their courage; and according to the intonation given to the tune these warriors made others tremble or trembled themselves. This musical strain was only a harmony of warlike sounds, we are informed, rathep than a set of words.

The moral of these remarks is pretty obvious, and has a fairly wide application; and it certainly does enter into our thoughts when we read about faith healing and the miracles at Lourdes, as well as when we are thinking about other and more commonplace matters.

For example, there is a general impression that ladies should be in the fashion. The creative lie goes forth that hats $3 \mathrm{ft}$. broad from brim to brim are all the fashion, and immediately every hat shop in the town will lay in a stock, and the rumour will send people in crowds to buy these head gears.

It is a precept of the Church that "works" are the ontward signs of what is proceeding in the Spirit. $A$ doctrine is set forth in a Papal Bull; thie is followed by "works" in the form of some wonderful recoveries at a certain shrine, and soon afterwards obedience in the acceptance of that doctrine by the people belonging to that Church becomes general. Who can prevent incredulous and sceptical folk irreverently alluding to those "cures" as an "exploitation of miracles"?

It is the universal wish to avoid the consequences of sin and evil; to be relieved of pain, and to escape death. It is widely promulgated that the way to attain these desired ends is fully explained in a volume entitled Science and Health, with Key to the Scriptures; and in thirty years the book claiming to give this instruction, though published at a preposterous price, passes through 200 editions and spreads its fallacies and falsities broadcast throughout a. credulous world.

\section{B. Christian Science Healing.}

The other form of healing by religious suggestion prevalent to-day is Christian Science healing. Faith healing differs from Christian Science in not masquerading in. senseless and meaningless metaphysics; in not asserting the non-existence, the nothingness, of matter; and in not discouraging the use of physical methods and materials as aids in the treatment of injuries and disease.

* "Sunt illis haec quoque carmina, quorum relatu, quem barditum. vocant, accendunt animos, futuraeque pugnae fortunam ipso cantu. augurantur; terrent enim trepidantve, prout sonuit ucies. Nec, tam 
The "very heart of Christian Science" is said to be contained in the following "immortal sentence":

There is no life, truth, intelligence, nor substance in matter All is infinite Mind and its infuite manifestation, for God is All in All. Spirit is immortal Truth; matter is mortal error. Spirit is the real and eternal; matter is the unreal and temporal. Spirit is God, and man is His image and likeness hence man is spiritual and not material.

In Christian Science healing, which is based upon "faith" in certain doctrines, the suggestion is that disease has no existence; that the individual who thinks himself ill or in pain is labouring under a false belief; that the only real being is God, the only reality the Divine Mind. and that " sin, sickness, disease, and death" are phantoms axising from an erroneous impression that there is such a thing as "life in matter."

The method of suggestion is both aural and telepathic. It is aural when the patient is spoken to, and emphatically assured that he is not ill, that the disease is imaginary. that God will not permit sickness. It is telepathic when the operator gives "absent treatment," which consists in repeating in thought the same or such like assurances; and when he sits, without speaking, but in concentrated thought, by the bedside of the patient.

The Christian Science healer, however, does not admit that his method is "suggestion," but asserts that healing $\mathrm{co}_{j}$ nsists in an increase of "spiritual force," whereby the $D$ vine influence dispels the illusions associated with matter, which Mrs. Eddy calls "mortal mind"-illusions which she says arise from the false belief in the existence of a body. Throughout her writing she is perplexingly inconsistent, and is constantly referring to matter in terms of mind, and to mind in terms of matter.

It is really difficult to study Christian Science with patience and composure, or, indeed, without impatience and mental irritation. It is quite possible to read about the miraculous cures at Lourdes with toleration and even with interest, howerer incredulous one may be; but the reading and study of Christian Science are simply insufferable.

Nevertheless, Christian Science has been studied and analysed with calmness and ability, and its flagrant errors have been exposed (1) by Canon Scott Holland, from the point of view of its false Christianity; (2) by Mr. Stephen Paget, from the standpoint of its failures as a therapentical power in sickness and disease; (3) by Miss Carta Sturge, from the metaphysical aspect; and (4) by Mark Twain, who has criticized it as a literary production written in third-rate English, full of glaring defects in expression and of unsoundness in argument.

Mark Twain's able analysis would have been even more telling than it is if there had been less of the music.hall wit in his criticisms, fewer slangy or colloquial Ameri. canisms, and less intermingling of the "funny man "with the clearness and brightness and pungency of the eloquent and facile writer. He has brought into prominence Mrs. Eddy's literary incapacity; hor meaningless sen. tences; her "intoxicated metaphor"; her want of con. sistency; her love of the dollar; her briskness in business; her inexorable rule over the mother church, the metaphysical college, and the ministers in all the branch churches; her punishment of those Christian Scientists who disobey her; and her assertion of infallibility and absolute authority, outstripping even the claims of Rome. Mark Twain's summary of her as a woman is "grasping, sordid, penurious, famishing for everything she seesmoney, power, glory-vain, untruthful, zealous, despotic, arrogant, insolont, pitiless where thinkers and hypnotists are concerned, illiterate, shallow, incapable of reasoning outside of commercial lines, immeasurably selfish."

Nor does a perusal of Mrs. Eddy's biography lead one to think that Mark Twain is too severe in his estimate of Mrs. Eddy's character. Undoubtedly she writes with great swelling words of vanity. Confusion of thought is made worse confounded by diction. She expresses indistinct ideas in meaningless phrases, which, however, are calcu. lated to give an impression of wisdom and knowledge to those who read without thinking, or who, being imperfectly educated, accept sound for sense.

The jumble and confusion in Mrs. Eddy's philosophy and the errors in her logic are well described by Miss Sturge, who points out how particularly mischievous in their practical results are the Christian Scientists' false conclusions from true premisses. She gives many illus. trations of this vicious reasoning, as, for instance, Mrs.
Eddy's use of such words as "life" in two senses, and her argument first from one sense and then from the other as suits her purpose. The reader untrained in logic, seeing the truth of the major premiss, unthinkingly takes for granted and swallows whole Mrs. Eddy's incongruous reasoning and inadmissible conclusion.

Mrs. Eddy's absolute denial of the reality of matter reminds on $\theta$ of what Byron said of the celebrated Biehop of Cloyne's scepticism concerning the non-existence of matter :

When Bishop Berkeley said "There is no matter" And proved it-'twas no matter what he said:

They say his system 'tis in vain to batter,

Too subtle for the airiest human head;

And yet who can believe it? I would shatter

Gladly all matter down to stone or lead,

Or adamant, to find the world a spirit

And wear my head, denying that $I$ wear it. Byron, Don Juan, Canto xi.

Space will not allow of further reference to either Canon H. S. Holland's essay or Mr. Stephen Paget's book. But I desire to comment on one side of Mrs. Eddy's mental organization which seems to have escaped the notice of her critics, and to have been entirely misrepresented by her admirers-namely, her natural temperament, or turn of mind.

The Importance of Temperament in a Propagandist.

The temperament of a writer or teacher is a matter of the greatest importance in appraising the sincerity and trustworthiness of his work.

Without consulting the writings of any of her hostile critics we can obtain from Mrs. Eddy's own writings and the biography written by her devoted and sympathetic admirer, Sibyl Wilbur, ample material for forming an opinion as to Mrs. Eddy's inherent character or tempera. ment. She was a precocious, emotional, argumentative child, prone to use long words and sage grave sayings, which she had learnt by rote in her close companionslip from infancy with her Scotch Covenanter grandmother, whose "dramatic tales of a land torn by religious dissensions for nearly a century" were poured into the eager ears of her little charge. Mary Baker (Mrs. Eddy's maiden name) was affected in her actions, and when 12 years of age began to hear "voices" and fancy herself "called" by her mother when she was not. At this tender age she contradicted and disputed with her father on religious questions so that he was led to say that "if Mary Magdalene had seven devils our Mary had ten." She showed herself to be a heartless and rery unnatural mother by parting with her only child and fatherless son when he was but 5 years of age, allowing him to go to live a long way off with a spinster nurse who was about to get married. For seven jears Mrs. Glover, as was then her name, never saw the child. She married her second husband, towards whom she professed indifference from the first, for the sake, we are told, of an independent home for herself and son. Not till three years after this marriage, however, did she go to see her son and have him to live in her house; and then only did she do so because of a mortgage on a property in which she and her husband were interested and which happened to bo in the district in which the boy was residing with his nurse and her husband. After a brief interval the boy was sent back to his foster parents, who removed away into the Far West. Mrs. Eddy saw no more of ber son after this for twenty.two years; neither did she communicate with him or he with her.

In 1888, when this son, then in his 47th year, proposed to come to her, she being then in her 70th year, Mrs. Eddy refused to receive him. It was said "Destiny still parted them with an insurmountable barrier." Nevertheless, at this very time she adopted a graduate of Hahneman Medical College, a homoeopathist, and a pupil of her own in Christian Science, who was five years junior to her own son. "This agreeable and accomplished man of 40 remained with Mrs. Eddy till 1896." She and he then had differences, and they parted; but Mrs. Eddy "did not however, erase him from her memory, for she yet speaks of him as her son." But with her own son she was shortly afterwards fighting lawsuits in equity respecting her property and his inheritance.

Daring four years before and eleven years after her second marriage she was an invalid " afflicted with a spinal 
weakness which caused spasmodic seizures, followed by prostration, which amounted to a complete nervous collapse."

Sometimes bedridden, at others actively getting about even to "speeding up steps like a deer," then again being rubbed with alcohol and lifted in and out of bed, she was regarded by the ladies of her acquaintance as an acting invalid making her husband a martyr to her whims. Once she rang the bell, and immediately after was found by the servant who answered "lying rigid with foam on her lips." She was an accomplished actress, as was shown on two occasions when she succesfully hoaxed a female acquaintance with whom she was living. This friend was a Mrs. Crosby, a great believer in spiritualism, who was much attracted by the description given by Mrs. Eddy of her deceased brother, Albert Baker. So Mrs. Eddy one day, when sitting with Mrs. Crosby, suddenly leaned back in her chair, shivered from head to foot, closed her eyes and began to talk to Mrs. Crosby in a deep, sepulchra voice, and purported to deliver a mes sage from the spirit of Albert Baker. On the following day she again pretended to go into a trance, and directed Mrs. Crosby as to where she would find letters from the spirit, and which she herself had written and placed there. Mrs. Eddy, who boasted that she had no belief in spiritualism, made a complete dupe of her friend Mrs. Crosby, the spiritualist.

The greatest event of Mrs. Eddy's life was an accident which occurred to her in Lynn, and which has been called with various shades of meaning her "fall." This fall resulted in what has the semblance of having been another unmistakable hoax. As she was walking home with friends on February 3rd, 1866, she slipped on ice, and is said to have suffered "a concussion of the brain and spinal dislocation, with prolonged anconsciousness and spasmodic seizures as concurrent symptoms." On the third day after this fall "God said to her 'Daughter, arise!'" and thereupon she got up from her bed quite recovered, and walked into the adjoining room, where her friends were awaiting her death. This was the most momentous occasion in her career. It was then that she caught from "the Divine Harmony a revelation of the Truth"; it was then the Bible miracles which before had seemed supernatural grew divinely natural and apprehensible; it was then she underwent " a cataclysmal upheaval," from which was to follow that " new under. standing of Christianity which would shake the world's thought to its center"; it was then she "made the discovery of the principle of Divine Science," of " "Christian Science mind healing,' and gave to the world in my work called 'Science and Health' the leaves that are for the "healing of the nations'"; and it was then she felt the hand of God laid upon her, and she learned the unique and powerful significance of the life which was before her. The sceptical surgeon with experience of concussion of the brain and dislocation of the spine might be Pyrrhonist enough to add that it was then also that Mrs. Eddy ex. hibited the deception of an impostor, the feigned illness of a malingerer, the tricks or "business" of an actress.

This "fall" and "miraculous recovery" were well timed. They happened about a month after Quimby's death, and when she could safely assert a claim to complete originality in the conception of her scheme of "science" without fear of contradiction from him.

From the date of her cure, when "Quimby may have allowed her to hypnotize herself with the thought that God was the 'Wisdom ' which Quimby brought to his patients," Mrs. Eddy's mind was thoroughly under the influence of Quimbyism. This system of Quimby was, her biographer says, nothing more than "an excrescence on the nataral growth of mental suggestion from Mesmer to the Nancy school."

In 1861 Mrs. Eddy corresponded with Quimby about her own health, and in 1862 she went to Portland, Maine, to be treated by him. He cured her instantaneously, and " set her free from the excruciating pain of years."

Quimby considered he had cured her in his usual way by imparting healthy electrical currents, together with his "Wisdom"; but Mrs. Eddy persistently would, through her "religious emotion engendered by years of suffering, ascribe to him a spiritual nature"; and she insisted that he had healed her "by virtue of his religious wisdom."

It would seem that jealousy of the success of "some of her former papils led her in 1872 to completely rid herself and her teaching of all relics of Quimby's influence, by repudiating mental suggestion and animal magnetism, and denouncing manipulation and all use of physical contact in the treatment of patients, as having no part or place in Christian Science healing. Many of her pupils, who by following her teaching had really been practising mesmerism, though some of them were apparently unaware of the fact, parted from her when she began to preach "the science of healing by soul power." They questioned the propriety of calling this treatment "Mind Science," "Moral Science," or healing by the Divine Spirit or by spiritual power, and they doubted the truth of the positions they were called upon to take up, as they were convinced they had been studying the "science of mesmerism." Even after she ceased to teach by lectures and writing only, and had published a complete statement of her system in her book, science and Health, the first edition of which was published in 1875, Mrs. Eddy was still mistrusted by those who knew her best; and her unchristian. like conduct caused her to be deserted by many of her disciples. Eight of her former followers brought an in. dictment against her in 1881 for "frequent ebullitions of temper, love of money, and the appearance of hypocrisy," and declined to submit any longer to such leadership.

Mrs. Eddy had always a longing to create "an effect." She craved notoriety; she loved to cause a sensation in some way, whether by attacks of "hysterical grief" or otherwise. She was exacting in authority, grasping in power, and safeguarded her material interests by infrangible copyrights. Mrs. Eddy says: "Impelled by God to set a price on my instruction in Christian Science mind healing, I was led to name 300 dollars for each pupil for one course of lessons at my college." Nearly $£ 60$ is a startling sum for tuition lasting barely three weeks. But "a strange providence" led her to accept this fee!

Though she would have the world believe that she was inspired to write, and that her book was given to her as a revelation, yet she was for years without any clear idea as to what system of healing she would proclaim as her. own. She had lived at more than one period of her life on intimate terms with spiritualists, and had, as we have seen, successfully practised spiritualism on her own account on at least two occasions. She had dabbled in homoeopathy; she had received personal instruction from, and possessed manuscript notes of the work and results of an out-and out mesmerist; and she had learnt also from Quimby something about a system of healing on a principle of belief.

Mrs. Edjy claims to have instantaneously cured a form of blindness in a baby by simply taking the child in her arms and looking at it; pet she had in her domestic service for years a blind maid whom she did not cure, but to whom she behaved inconsiderately by making her walk six miles behind the conveyance in which she herself was travelling from Groton to Rumney on the occasion of their giving up their residence in the former place-the village church bells being tolled in derision as she and her second husband were departing therefrom.

Her first husband had died within a year of their marriage; her second husband, whose simplest attentions to her provoked, we are told, the jealousy of all other women, so universally was he in request by the fair sex, at length left her, and Mrs. Eddy obtained a divorce from him in 1873. In 1877 she made what she spoke of as "a spiritual union" by marrying, as her third husband, Mr. Eddy. Mr. Eddy was agent for a. "sewing-machine concern," not in good health, and was spoken of by persons who knew him as "devoid of the true force of manliness." He consulted Mrs. Eddy about. his health, she advised him to enter a new class she was. forming, and, having read aright the submissive and conciliatory nature of his character, she married him "in the midst of the struggles of personalities" with several former pupils; and made him her agent and the guardian of herself "against the onslaughts of the envious and ambitious who pressed too closely with their human desires." Mrs. Eddy introduced her new husband to her class with an address, followed by a reading of the Bible. Then she expounded certain passages, whilst the students beheld their teacher and leader "with hands as ever outstretched to them with the spiritual gift to be transferred through them to the whole human race and to the age." "Mr. Eddy at this moment became. simply one of them ... he, like them must carry out her directions that the spreading of Christian Science should 
not languish." In the year following their marriage $\mathbf{M r}$. Eddy, by a strange conspiracy on the part of some of Mrs. Eddy's old pupils and now professional enemies, was charged with murder. There was no foundation in fact for the charge; but the worry of it, and of the lawsuits in which Mrs. Eddy was engaged in connexion with plagiarism of her book, and plans which threatened " to wrest the leadership of Christian Science from its discoverer," caused Mr. Eddy to regard these attacks as "an exhibition of malicious animal magnetism" on the part of his wife's aggressors and competitors.

Now, after learning the character of Mr. Eddy, one is not surprised to read that he became convinced he was the victim of an affection caused by "the suggestion of evil," and that he was being poisoned by a suggestion of arsenical poison made by two of his hostile acquaintances.

He died of heart disease in 1882, and just before he expired he cried out: "Only rid me of this suggestion of poison and I will recover."

What are we to think of the founder of Christian Science who neither alone, nor in conjunction with her afflicted husband, himself a Christian Scientist, could call effectively. on the Divine Spirit, or successfully draw upon "spiritual force" to remove the impending fate-namely death-which though elsewhere she says is an unreality, is yet about to carry off her husband by "an idea" of poisoning? And what is the meaning of her sneers at " suggestion," seeing she told the physician, whom she summoned in the last stage of the illness, that "she believed her husband was suffering from " the suggestion of arsenical poisoning, that she did not believe that his heart was defective, but that he was suffering from suggestion; and, later on, that poison mentally administered killed her husband? "Not material poison," she declared, "but mesmeric poison."

What are we to think of such a philosophy of disease and death? Of such a philosopher, who had told Quimby "the illiterate mesmerist, Quimby the blundering and stumbling reasoner," that the healing resulting from his hypnotic practice was in reality due to " his knowledge of God's law, his understanding of the truth which Christ brought into the world, and which had been lost for ages"?

It seems incredible that any one who has given thought to Mrs. Eddy's so.called philosophy or science can have the least faith in her system of healing, her doctrine of treatment. We have seen from her own statements how many of her pupils did fall away and revolt from her teaching and pretensions, some of whom went on practising mesmerism.

One can no longer wonder at the absurdities of her philosophy, nor at the cruelty and folly of her Christian Science treatment of disease, after a study of her temperament and conduct. Her work was conceived in ignorance and vanity; reared in profane audacity, and the most presumptuous and selfish ambition; developed in deceit, disharmony, and strife; and culminated in hypocrisy, cupidity, and lust of power.

What a contrast there is between the miracles of healing related in the Gospels and the miserable travesties, failures, and tragedies of the Christian Science healing !

The cures wrought by Christ were instantaneous, com. plete, and perfect. The blind received their gight, the lame walked, the lepers were cleansed, and the deaf heard, the dead were raised up, and the poor had the Gospel preached to them. But there was no boasting of the wonders worked, no exploitation of the miracles performed. "Go and show John those things," but at the same time "see that thou tellest no man," were the injunctions given. In the case of the man of the country of the Gadarenes who called himself "Legion" because many devils were entered into him, instruction, it is true, was given to him to " return to his own house and show how great things God hath done unto thee." But we can understand that for the peace of mind of others there were special reasons why a person whose dwelling had been among the tombs, who had worn no clothes, and whom no man could bind, no, not with chains, should not go away with Christ, but remain behind "clothed and in his right mind," as a consoling witness that the unclean spirits had departed and were buried in the sea.

But the Christian Scientists, on the other hand, pro. claim aloud at all their meetings their vanquishment of disease, as well as their victories over drunkenness, morphine, and immorality. They are incessantly making "triumphant assertions of the health and power" derived from their cult. Nor was there, in the case of the gospel miracles of healing, as I have specially pointed out elsewhere, rejection or neglect of physical aids either during or after the cure or the restoration to life. Jairus's daughter, for instance, was taken by the hand and told to arise; and when she arose Christ "commanded to give her meat," and her parents were charged "that they should tell no man what was done." But with Christian Science there is bungling, shilly-shallying, and worse. Relief is withheld, irreparable mischief is done, and life is lost through this misguiding and misguided "treatment."

Of Mrs. Eddy's own cases of reputed cures there is not one that I can find substantiated by reliable and independent evidence. Notwithstanding this, notoriety and publicity are courted, attention is attracted, men's eyes are drawn to the cures which are claimed, and Mrs. Eddy impiously asserts that God prepared her 'daring many years for the reception of a final revelation of the absolute principle of scientific being and healing." At the same time, it is asserted with blasphemous audacity that she rediscovered and applied the definite rules whereby Jesus Chrisq performed His miracles of healing sin, and disease.

Compared with the Lourdes craze, Christian Science is as a snaxe and a pitfall to a refuge and a haven of security. No deprivation of medical treatment, or of physical aids to comfort or relief is required by the former; no excuse for failure is sought in extraneous trifles to pacify or impose upon the disappointed pilgrims to the Grotto.

\section{The Lives of the Founders of Great Religious} Movements.

It is distastefal, indeed hatefal, to write thus of any one, especially of a very aged woman. But it is not the woman as an individual but the founder of a sect, the "Pastor Emeritus" of a church, college, and community, the boasted author of "the greatest religious movement of modern times," whose character I have been examining and interrogating.

The lives of the founders of all the great religious movements of the past have been the subject of searching criticism and unsparing and rigorous investigation. The Buddha, Mohammed, and Mohammed's immediate successor have again and again been submitted to the fallest inquiry. The Founder of Christianity throughout His career on earth was exposed, and exposed Himself willingly, to constant interrogation and searching curiosity. Every part of His life was a befitting piece of a consistent and perfect whole. He came into the world to save sinners. He was manifested to take away our sins, and made "to be sin for us, who knew no sin"; and when towards the end of His mundane existence He asked of the Jews that boasted of Abraham being their father, "Which of you convinceth $\mathrm{Me}$ of sin?" though they sought to kill Him, they were unable to meet the challenge to bring any sin against Him.

Even Bernadette and the other little shepherdesses in the Pyrenees who saw the apparitions and were made the mouthpieces of the Immaculate Virgin instantly knew their mission; and youthful, simple, and unlettered as they were, set themselves immediately to discharge it. Having done so, they retired into the sanctity of the cloister, leaving the continuation of the work commenced through them to be carried on by a wily priestcraft and a wondering world.

But not so the apostle of Christian Science. Her " moral science" teaching was repudiated, her conduct was justly condemned, and she was abandoned by many of her disciples. She had floundered in and out of her depth without knowing what it was she was going to do. She had oscillated from one "ism" to another till at length she declared in favour of " arsenical poisoning by suggestion." But mean. while, and thereby, she was reaping a rich harvest, and was garnering up a very considerable fortune.

\section{"Christian Science Lacks even Glowworm} Luminosity."

The fundamental principle of Christian Science is the assertion of the unity which underlies the universe. "God is all." "The One in which everything has its reality is of the natare of Mind, Intelligence, Life, or Spirit." But this principle, though true, is not new. It underlies the speculative and scientific thought of 2,000 years and more. Philosophers and scientists in all ages have referred back their experiences to an underlying unity, whether they 
have tried to find this Ultimate Unity in an Element, Number, or Idea.

But the only deduction Mrs. Eddy can make from this great principle is that, "God, Spirit being all," there is no such thing as matter.

The great invention of Christian Science is "mortal mind." By this phrase Mrs. Eddy means something untrue, unreal, something which has no existence. She calls "sickness and sinfal humanity mortal mind-meaning by this term, the Flesh opposed to Spirit." The ills of the flesh, which are part of matter or "mortal mind," and as such are merely false idess and non-existent, must be annihilated by the Divine Spirit, not by means of medicines presented by physicians. Healing will be accomplished by the "Supreme and only reality," for "the realm of the real is Spirit."

What a contrast to the Christian creed of the Creation is the World as described by the founder of so-called Christian Science! When darkness was upon the face of the deep and the Spirit moved upon the face of the waters the word went forth, "Let there be light and there was light" ; and it was seen that the light was good, and was divided from the darkness. Bat when the author of Science and Health, with Key to the Scriptures, attempts to throw light upon the dark places of science and religion, she cannot supply us with even a glow worm luminosity.

Portia, when returning home to Belmont, after getting justice done to Antonio by outwitting Shylock, seeing a light burning in the ball of her house, exclaimed.

How far that little candle throws his beams,

But Nerissa remarked in response :

When the moon shone we did not see the candle.

And Portia answered:

So doth the greater glory dim the less:

A substitute shines brightly as a king

Until a king be by.

From Mrz. Eddy's work no light is emitted. Her treat. ment of "The Fandamental Principle," "The Unity," is too bewilderingly unintelligible. Her vagueness and miscon. ceptions exclude all daylight from her writings, and her philosophy affords no kind of illumination.

When common sense, not to say logical reasoning, steps in, it acts on Mrs. Eddy's metaphysics like Nerissa's moon. shine or Portia's little candle, like the king on his substitute.

\section{"Faith.Abounds without the Aid of Christian} Science."

It is not within my purpose here to dilate upon the spiritual service which Christian Science is said to have rendered many souls by engendering within them the virtues of faith, fortitude, endurance, and self.control.

In any case, we have to set over against such service the terrible and fatal disservice Christian Science has dispensed in multitudinous instances by its cruel and heartless treatment of physical suffering and disease.

If Christian Science has done good in a spiritual manner to any one by arousing or increasing faith-and I am not prepared to deny that it has done this-so much the better, as this is at least something towards connter. balancing the enormous evils of its mistaken and criminally erroneous treatment of the body. But it is harmful to do evil even though some good may come out of it.

Fortunately, however, it has been permitted to us to learn the value, the comfort, and the helpfulness of faith without having to condone or acquiesce in the danger and absurdity of faith healing in its Christian Science garb.

Faith, indeed, is much; perhaps it is really everything to man. Happily, it was given to him ages before the atrocities of Christian Science were dreamed of.

A far better and truer way of explaining its action in mental affliction and bodily suffering may be gleaned from the following extract from Carlyle, with which I must bring to an end this lengthy but imperfect article:

"An inward force has been given to man whereby he is enabled to withstand the pressure of things odtward. Obstruction abounded; but Faith also was not wanting. It is by Faith that man removes mountains : while he had Faith, his limbs might be wearied with toiling, his back galled with bearing; but the heart within him was peace. able and resolved. In the thickest gloom there burnt a lamp to guide him. If he struggled and suffered, he felt. that it even should be so; knew for what he was suffering. and struggling. Faith gave him an inward Willingness, a world of Strength wherewith to front a world of Difficulty. The true wretchedness lies here; that the Difficalty remain and the Strength be lost; that Pain cannot relieve itself in free effort; that we have the Labour. and want the Willingness. Faith strengthens us, enlightens us, for all endeavours and endurances; with. Faith we can do all, and dare all, and life itself has a thousand times been joyfully given away."

1 Europe, vol, ix, pp. 79, 80.2 Carlyle : Characteristics, Essaysi. vol. iii, p. 22

\section{REMARKS ON SPIRITUAL HEALING. BY}

H. T. BUTLIN, F.R.C.S., D.C.L., LL.D.,

PRESIDENT OF THE ROYAL COLLEGE OF SURGEONS OF ENGLAND AND PRESIDENT-ELECT OF THE BRITISH MEDICAL ASSOCIATION.

The cases of two patients from my private practice, who have been mixed up with faith healers, have come to the notice of the British Medical Association, * and that, $I$ think, has led the Editor of the Journat to imagine that $I$. have had a much larger experience of faith healers than really is the case. I only remember one other of my patients who belonged to a sect of faith healers (Note I), and I have not met with any number of persons, so far as I am aware, on whom the agency of faith has been employed for the cure of their disease.

On the other hand, I have always had an indirect. interest in spiritual healing, for a member of my family is said to have the gift of healing by faith. We have supplied quite a number of clergymen to the Church of England, most of them of the very low Church. Many years ago I was informed by letter that one of these clergymen was endowed with such great and lively faith that he was able to cure the sick, and that he had actually cured two of: his own household by anointing them and praying oven them. I was asked to express my opinion on this very important matter, and I am sure it was expected that I should. remonstrateand say it was nonsense or the effect of imagination. But I did not do so. I at once wrote to offer my con. gratulations and to express my pleasure, and to say that I saw many persons whom I could not cure, particularly persons afflicted with cancer, and that I should be delighted if $\mathrm{my}$ relative, the clergyman, would take over and care the cases which were beyond my art. My disappointment may be imagined when I received a letter informing me that it was not given to him to cure other persons than. those who also believed. From this I perceived that mutual faith was necessary, and, as I could not feel con. fident that I should be able to provide patients of so stron:s a faith as this, no further negotiations took place. I have, however, at rare intervals, held conversations with this clergyman on healing by faitb, and the matter has often been before my mind, although I have never, until now, spoken or written on it.

It has always seemed to me that our profession has beer disposed to take too narrow a view of spiritual healing. In the opinion of many medical men the cares are only effected on impostors who permit themselves to be cured, and on neuro-mimetics, who are cured of maladies which they have never had; and the persons who proclaim these cures, for the most part ecclesiastics, are either too ignorant to distinguish between real and feigned conditions of disease, or are themselves impostors, sometimes cometimes banded together deliberately to deceive the public, either for their own individual ends or for the benefit of the religious community to which they belong. In some of these communities the ecclesiastic is bimself the healer, the on]y intermediary between the Almighty and the patient; in other communities the intermediary is a saint or virgin, and the ecclesiastic assists and encourages the patient to approach the intermediarv

* British Medical Journal, 1909, vol. i., p. 1253. This case forme the substance of a leading article. The second case has not been published, but has been referred to a Committee of the Association. The papiritual means. 